\title{
Causes of embryonic mortality in Espadarana prosoblepon (Anura: Centrolenidae) from Costa Rica
}

\author{
Johana Goyes Vallejos ${ }^{1,2}$ and Karim Ramirez-Soto ${ }^{3}$ \\ ${ }^{1}$ Biodiversity Institute, University of Kansas. Lawrence, KS 66045, USA. \\ ${ }^{2}$ Current address: Division of Biological Sciences, University of Missouri. Columbia, MO 65211, USA. E-mail: goyes. \\ johana@gmail.com. \\ ${ }^{3}$ Glendale Community College. Glendale, AZ 85302, USA.
}

\begin{abstract}
Causes of embryonic mortality in Espadarana prosoblepon (Anura: Centrolenidae) from Costa Rica. Members of the family Centrolenidae-commonly known as "glass frogs"- exhibit arboreal egg-laying behavior, depositing their clutches on riparian vegetation. Few studies have investigated specific causes of mortality during embryonic stages, perhaps the most vulnerable stage during the anuran life cycle. The Emerald Glass Frog, Espadarana prosoblepon, was used as a case study to investigate the causes of embryonic mortality in a species with short-term (i.e., less than 1 day) parental care. The specific sources of mortality of eggs of E. prosoblepon were quantified and overall rates of survival (hatching success) were estimated. Nineteen egg clutches were transferred from permanent outside enclosures to the wild. Clutch development was monitored daily until hatching; five mortality causes were quantified: desiccation, failure to develop, fungal infection, predation, and "rain-stripped." The main causes of mortality were predation (often by katydids and wasps) and embryos stripped from the leaf during heavy rains. The results were compared to those of previous studies of centrolenids exhibiting parental care, and discussed in the context of the importance of the natural history data for these frogs with regard to understanding the evolutionary history of parental care in glass frogs.
\end{abstract}

Keywords: Egg clutch, Emerald Glass Frog, hatching success, predation.

\section{Resumo}

Causas de mortalidade embrionária em Espadarana prosoblepon (Anura: Centrolenidae) da Costa Rica. Membros da família Centrolenidae-comumente conhecidos como "pererecas-devidro"-exibem o comportamento arborícola de postura de ovos, depositando suas desovas na vegetação ripária. Poucos estudos investigaram causas específicas de mortalidade durante estágios embrionários, talvez o estágio mais vulnerável durante o ciclo de vida dos anuros. A perereca-devidro-esmeralda, Espadarana prosoblepon, foi usada em um estudo de caso para investigar as causas

Received 15 October 2019 


\begin{abstract}
da mortalidade embrionária em uma espécie com curto período de cuidado parental (menos de 1 dia). As causas específicas de mortalidade de ovos de E. prosoblepon foram quantificadas e as taxas gerais de sobrevivência (sucesso de incubação) foram estimadas. Dezenove desovas foram transferidas de recintos externos permanentes para a natureza. O desenvolvimento da desova foi monitorado diariamente até a eclosão; foram quantificadas cinco causas de mortalidade: dessecamento, falha no desenvolvimento, infecção fúngica, predação e retirada pela chuva. As principais causas de mortalidade foram a predação (geralmente por gafanhotos e vespas) e embriões arrancados da folha durante fortes chuvas. Os resultados foram comparados com os de estudos anteriores de centrolenídeos que exibem cuidados parentais e discutidos no contexto da importância dos dados da história natural para essas pererecas no que diz respeito à compreensão da história evolutiva do cuidado parental em pererecas-de-vidro.
\end{abstract}

Palavras-chave: desova, perereca-de-vidro-esmeralda, predação, sucesso de eclosão.

\section{Introduction}

Some amphibian species have evolved nonaquatic oviposition (terrestrial, arboreal; reviewed in Wells 2007). It is thought that laying eggs in terrestrial environments evolved as a result of the selective pressure of aquatic predators (Magnusson and Hero 1991). Clutches laid in terrestrial or arboreal environments benefit from increased oxygen exchange and the "release" from aquatic predators (Duellman and Trueb 1986); however, other risks, such as desiccation, predation, and fungal infection, arise during this vulnerable life stage (Vonesh 2000, Warkentin 2000, Warkentin et al. 2001, Touchon and Warkentin 2009).

Members of the glass frog family (Anura: Centrolenidae) deposit clutches out of the water, on surfaces of leaves or other vegetation, overhanging streams. Centrolenids are particularly interesting, because in some species, parental care involves egg attendance (McDiarmid 1978, Guayasamin et al. 2009). However, the breeding and parental care behavior of only a handful of the 157 species (12 genera; Frost 2019) has been studied in detail. Much remains to be learned about other aspects of centrolenid reproductive ecology and the natural history of most species of glass frogs (Cisneros-Heredia and McDiarmid 2007, Delia et al. 2010). Thus, comparative studies to explore the evolution of these behaviors are challenging (but see Delia et al. 2017) and additional studies are needed to provide a broader understanding of extrinsic factors that may have favored behavioral strategies to maximize embryonic and larval survival.

Embryonic stages are vulnerable and those that develop out of the water, face specific risks (Warkentin 2011). Several studies of the reproductive ecology and parental care behavior in glass frogs have assessed specific causes of embryonic mortality (Vockenhuber et al. 2009, Delia et al. 2013, 2019, Lehtinen et al. 2014, Bravo-Valencia and Delia 2016, Hughey et al. 2017, Salgado and Guayasamin 2018). But few have focused on the causes of embryonic mortality in species with short-term (i.e., less than 1 day) parental care, and embryonic mortality sources have been identified in only two taxa-Teratohyla pulverata (Peters, 1873) and Cochranella granulosa (Taylor, 1949) (Hawley 2006, Delia et al. 2017). We investigated the causes of embryonic mortality in the Emerald Glass Frog, Espadarana prosoblepon (Boettger, 1892), a species in which the female remains with the clutch fewer than $3 \mathrm{hr}$ after oviposition (Jacobson 1985).

Espadarana prosoblepon occurs in Central and South America from Honduras to Ecuador (Savage 2002). Males have humeral "spines" on their forearms, and use these spines in territorial 
combats (Figure 1). Females lack humeral spines and are slightly larger than males (Hedman and Hughey 2014). Males call from the upper surfaces of leaves and other vegetation near small streams to attract females. After amplexus, females lay their eggs on the upper surfaces of leaves, moss-covered rocks, tree trunks, or branches (Jacobson 1985).

Despite its wide geographic range, relatively little is known about the reproductive biology of Espadarana prosoblepon-especially its parental care behavior and other aspects of its embryonic development. Jacobson (1985) studied a population from Monteverde (northwestern Costa Rica) and described key aspects of its mating behavior and reproductive biology, including clutch size, male reproductive success, and amplexus behavior. Jacobson reported that about half of the observed clutches hatched successfully, with "success" defined as more than $70 \%$ of the embryos hatching; however, the sources of embryonic mortality were not described in detail. Research exploring other aspects of the natural history of this species has increased recently and include experimental studies on the use of humeral spines and malemale aggressive behavior (Hedman and Hughey 2014, Krohn and Voyles 2014), estimates of survival and abundance (McCaffery and Lips 2013), and population declines after the arrival of the amphibian killing fungus Batrachochytrium dendrobatidis Longcore, Pessier, and D.K. Nichols, 1999 (Angeli et al. 2015). BastoRiascos et al. (2017a) reported several aspects of the reproductive biology of $E$. prosoblepon in a population from the Andes of Colombia, including oviposition-site use and mating patterns. Additionally, a few natural history observations on fungal infections (GuayaraBarragán et al. 2010) and predation of embryos by spiders (Basto-Riascos et al. 2017b) have been published. However, there are no studies investigating embryonic survival or specific causes of embryonic mortality other than these opportunistic accounts.
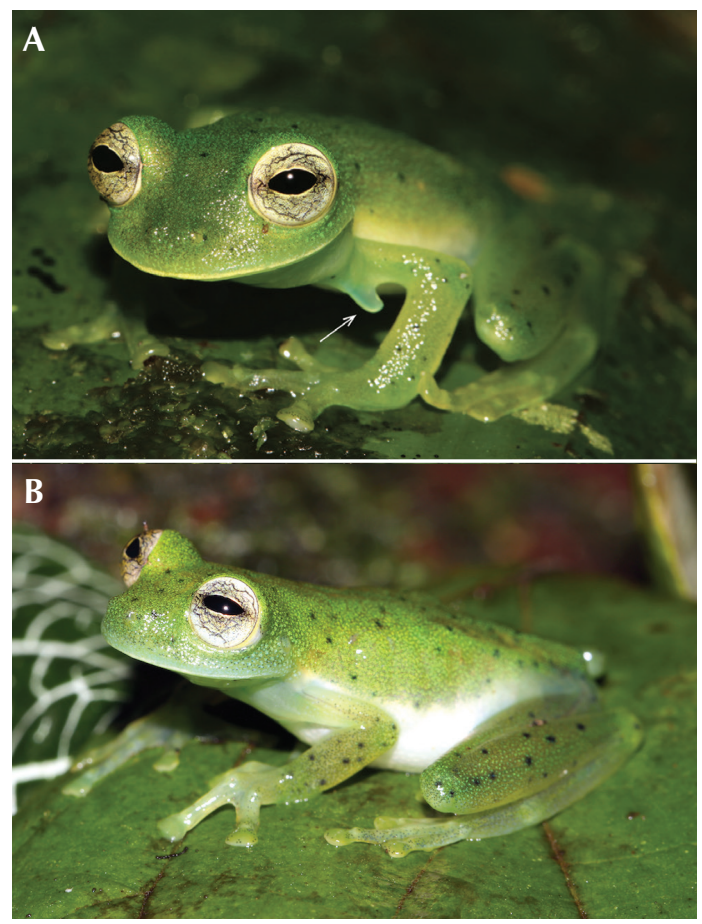

Figure 1. Sexual dimorphism in Espadarana prosoblepon. (A) Males have noticeable humeral spines on their forearms (white arrow). (B) Females lack humeral spines. Photo: JGV.

\section{Materials and Methods}

\section{Study Area and Fieldwork}

This study took place between 11 June and 12 July 2018, at Las Cruces Biological Station, San Vito, Puntarenas Province, Costa Rica $\left(8.7858^{\circ} \mathrm{N}, 82.9589^{\circ} \mathrm{W}\right)$. Every night, we searched for pairs of Espadarana prosoblepon in amplexus, starting at 20:00 h (Figure 2A). The study area was about $500 \mathrm{~m}^{2}$, surrounding a 60-m segment of a small stream ("Culvert Creek") at the field station. When an amplectant pair was found, we transferred them (handling the pair carefully, to avoid dislodging the male) to a permanent enclosure that was located adjacent to the stream, thereby ensuring natural 
temperature and humidity conditions. The enclosure had four partitions adjacent to each other, consisting of $38 \times 50 \times 75-\mathrm{cm}$ chambers, surrounded by green wire mesh (Figure 2B). Each partition was provided with leaf litter for refuge during the day, a water bowl, and a pinna (single leaflet) of a fern, Angiopteris evecta (G. Forst.) Hoffm., hung from the corner; the fern is an oviposition substrate observed in the field (JGV, pers. obs.). We controlled for one potential source of variation that might affect hatching success by providing identical oviposition sites. Pairs were left overnight and the following morning, we checked whether oviposition had occurred (Figure 2C). After successful oviposition, both males and females were measured (snout-vent length in $\mathrm{mm}$ ), toeclipped, and photographed for individual identification, and then released where they had been captured.

\section{Embryonic Mortality Causes and Hatching Success}

To evaluate the sources of embryonic mortality, we transferred clutches obtained in captivity to sites where natural clutches had been observed during the weeks prior to the start of this study (JGV, pers. obs.). Pairs of Espadarana prosoblepon deposited clutches on the surface of individual pinnules of Angiopteris evecta provided inside the enclosures. Each clutch was transferred along with the pinnule and secured to a natural substrate (overhanging vegetation) with a cable tie (Figure 3D). We marked the location of the clutch with flagging tape, counted the number of eggs, and recorded the height at which each clutch was placed above water; all clutches were separated by at least $1 \mathrm{~m}$ (Figure 2E).

We monitored all clutches three times per day, and for each observation, we counted the total number of eggs (to determine the mean percentage of clutch mortality), noted developmental stage, and identified sources of embryonic mortality. Based on previously published descriptions (McDiarmid 1978, Warkentin 2000, Hawley 2006), five categories of mortality were recognized: (1) unfertilized eggs or embryos that failed to develop, with eggs turning white and disintegrating, or embryos that cease development before or at Gosner Stage 18 (Gosner 1960); (2) fungal infection, with eggs turning cloudy and hyphae apparent on the surface; (3) desiccation, with eggs failing to develop and having almost no jelly around them; (4) drowning or "rain-stripped," with the entire clutch disappearing after periods of heavy precipitation; and (5) predation, with eggs or late-stage embryos disappearing, especially around the edges of the clutch with some embryos remaining in the center, or by "empty" gelatinous masses before hatching occurred. Clutches were monitored until all surviving embryos hatched into a plastic cup placed beneath each clutch (Hayes 1983). We determined embryonic hatching success as the number of hatched tadpoles relative to the initial number of eggs per clutch. Also, we calculated the mean percentage of clutch mortality for each of the identified sources of mortality.

\section{Results}

We monitored 19 clutches in this study. The average clutch size was $25 \pm 6$ SD eggs (range $=$ 15-41). Clutches were relocated at an average height of $0.98 \pm 0.24 \mathrm{~m}$ (range $=0.55-1.45)$. The average embryonic hatching success per clutch was $14.5 \%( \pm 26.3 \mathrm{SD}$, range $=0-84.2 \%)$, with only two clutches having hatching success greater than $70 \%$. We identified five causes of embryo mortality: desiccation (1 of 19 clutches); failure to develop or failure to fertilize the eggs (14 of 19 clutches); fungal infection (2 of 19 clutches); predation (9 of 19 clutches); and loss of egg clutches in heavy rain (10 of 19 clutches). The mean percentages of clutch mortality attributed to different mortality causes are shown in Figure 3. Predation caused the most clutch mortality $(40.1 \%$, Figure 4$)$, followed by rainstripped embryos (31.2\%), and failure to develop $(12.4 \%)$. We observed wasps (Polibya sp.), and a katydid (Copiphora cultricornis Pictet, 1888) 

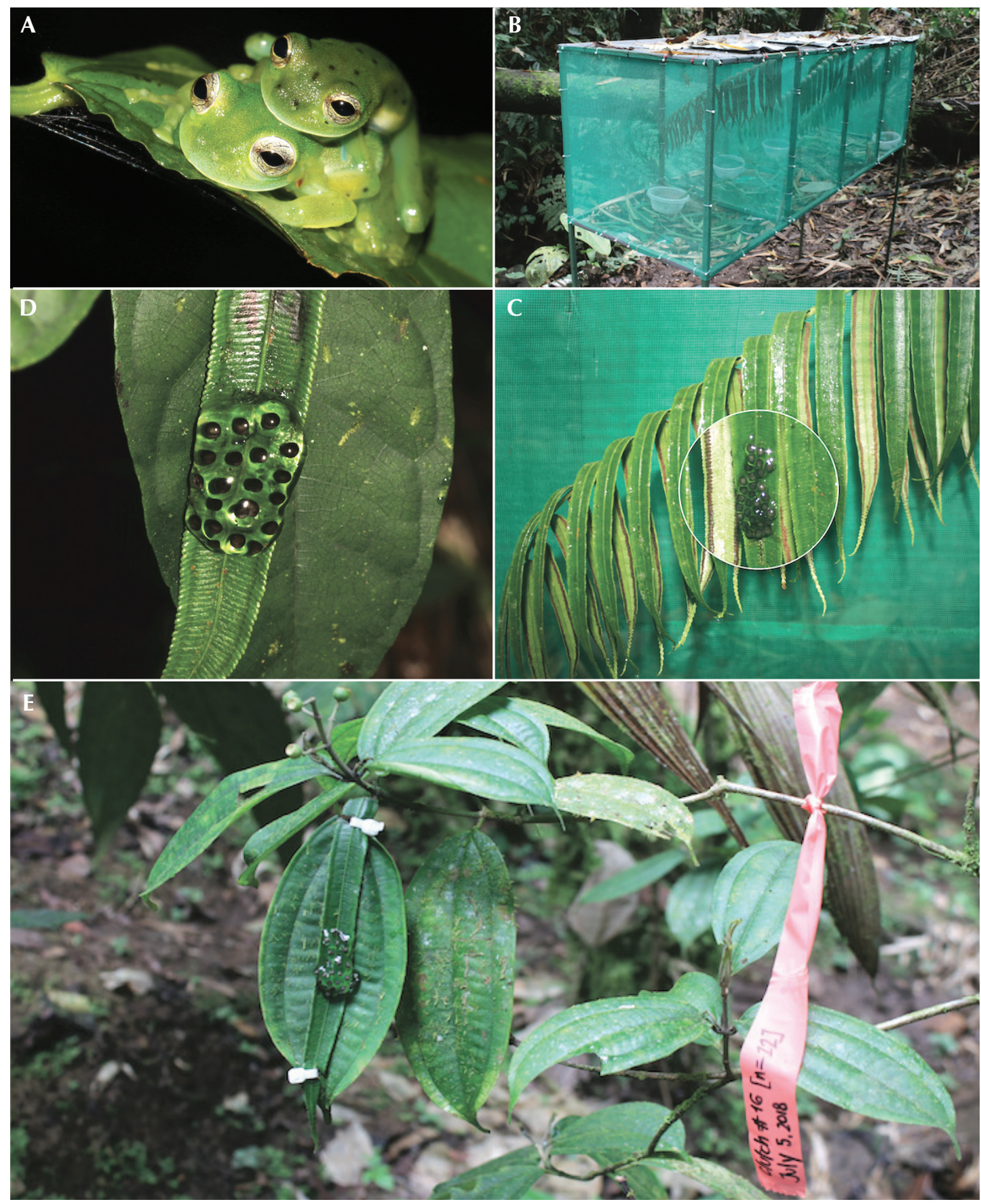

Figure 2. Transfer of egg clutches of Espadarana prosoblepon. (A) A pair of E. prosoblepon in amplexus. (B) Pairs were captured and placed in an enclosure and left overnight. (C, D) After successful oviposition, the leaflets with the clutch were cut and transferred to a natural substrate. (E) Clutch location was marked with flagging tape and included clutch number, clutch size, and day of oviposition. 
preying upon embryos on two and one occasions, respectively. In most of the clutches, up to $53.8 \%$ of embryos failed to develop. In contrast, predation and heavy rain caused the loss of more than $75 \%$ of the embryos in at least eight $(42 \%$ of clutches) and five (26\% of clutches) of the clutches, respectively.

\section{Discussion}

\section{Clutch Size and Hatching Success in}

Espadarana prosoblepon

The clutch sizes in Espadarana prosoblepon are similar to those previously reported for the Monteverde population (Jacobson 1985). However, a study conducted in the Colombian Andes reported an average clutch size of $35.4 \pm$ 4.8 eggs (range $=30-50, N=29$; Basto-Riascos et al. 2017a), which is substantially greater than those we observed.

Embryonic hatching success was low (14\%) relative to previously reported hatching success rates in other centrolenid species. In Teratohyla pulverata, a species with short-term parental care, embryonic survivorship is high (85\%) with low levels of predation and with most clutches suffering from developmental abnormalities (Hawley 2006). In a Mexican population of Hyalinobatrachium fleischmanni (Boettger, 1893), a species in which males brood the eggs, the average embryonic survival is $90 \%$, with scarcely any predation occurring (Delia et al. 2013). The wet season at our study site in Puntarenas, Costa Rica, extends from MayNovember, with a short drought called "El veranillo de San Juan" lasting about 10 days in mid-June. Most of the monitored clutches of $E$. prosoblepon from Monteverde were laid after mid-August, with estimates of embryonic survival of $47 \%$ (Jacobson 1985). As the wet season progresses, it is possible that embryonic survival in E. prosoblepon increases. Also, we should point out that given changes in temperature and precipitation patterns with climate change (Blaustein et al. 2010),

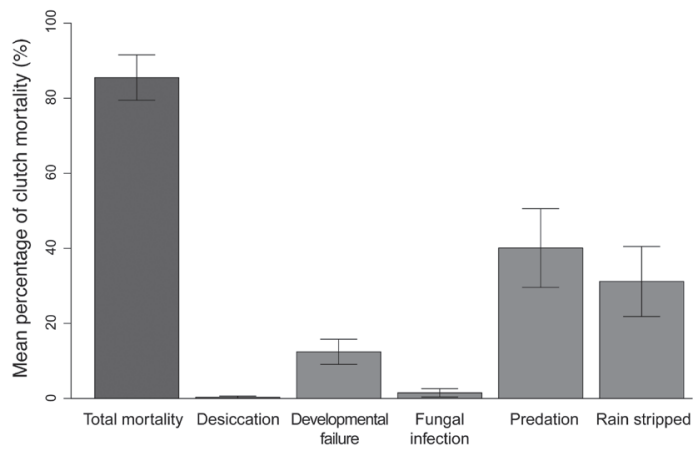

Figure 3. Mean percentage \pm SE of egg/embryo mortality in clutches of $E$. prosoblepon resulting from desiccation, failure to develop, fungal infection, predation, and rain-stripping.

centrolenid populations may experience longterm declines as a result of desiccation of egg clutches during dry periods or rain-stripping of the clutches during periods of unusually heavy rain (e.g., El Niño years) (Pounds et al. 1999).

\section{Causes of Embryonic Mortality in Espadarana prosoblepon}

The main causes of embryonic mortality in Espadarana prosoblepon were predation and rain stripping of clutches. Removal experiments comparing survival and hatching success between attended and unattended clutches in centrolenids have shown that egg attendance reduces dessication and sometimes provided protection against predators. (Vockenhuber et al. 2009, Delia et al. 2013, 2017, Lehtinen et al. 2014, Bravo-Valencia and Delia 2016, Hughey et al. 2017, Salgado and Guayasamin 2018). In only one case, Hyalinobatrachium valerioi (Dunn, 1931), was predation the main cause of mortality in both attended and unattended clutches (Vockenhuber et al. 2009). These observations suggest that the risk of desiccation may be a stronger driver of the evolution of egg-brooding behavior than the risk of predation. 


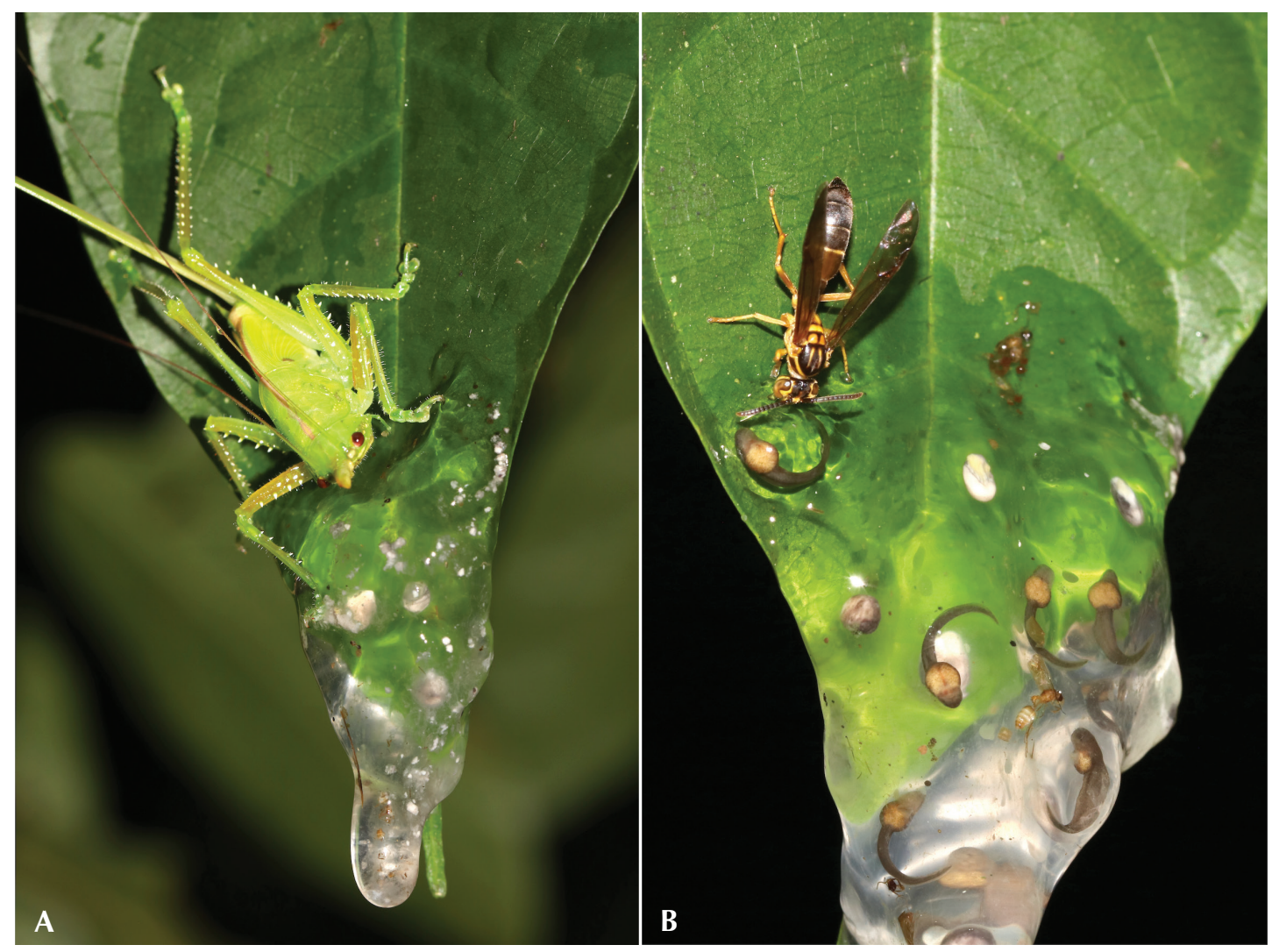

Figure 4. A katydid Copiphora cultricornis (A) and a wasp Polybia sp. (B) consuming embryos of Espadarana prosoblepon. Photos: JGV

Future studies should investigate whether predation rates change throughout the breeding season in E. prosoblepon. For example, in Hyalinobatrachium orientale (Rivero, 1968), predation is more prevalent in unattended clutches during the wet season than during the dry season (Lehtinen et al. 2014). Rain-stripping does not seem to be a primary source of embryonic mortality in other centrolenid species as it is in E. prosoblepon, in which "clutch drowning" affected more than half of the clutches. In most species for which rain-stripping has been reported as a source of embryonic mortality, less than $10 \%$ of the embryos were lost to heavy rains (Delia et al. 2013, 2017,
Bravo-Valencia and Delia 2016, Hughey et al. 2017).

Environmental conditions (i.e., humidity, temperature, and rainfall) in our mesh enclosure were the same as in the surrounding area. Height and substrate of oviposition sites are known to influence embryonic survival in E. prosoblepon (Jacobson 1985). By controlling for both of these factors, we attempted to reduce variation in mortality causes resulting from properties of the oviposition site itself, such as antimicrobial properties of the leaf, as suggested by BastoRiascos et al. (2017a) or the amount of water held by the substrate (e.g., moss vs. leaf surface). To the best of our knowledge, no studies have 
investigated the adaptive benefits of ovipositionsite choice in centrolenids. Additional studies are necessary to determine whether oviposition-site preferences counteract the effect of predation, and whether behavioral strategies (e.g., laying eggs in hidden places sheltered from heavy rains and predators) decrease mortality risks. Future studies should combine experimental approaches with natural history observations, to test whether the choice of oviposition sites has an impact on embryonic survival.

We have reported a high percentage of developmental abnormalities or unfertilized eggs in contrast to the results of other studies in which these sources of mortality accounted for less than 5\% of embryo deaths (Delia et al. 2013, 2017, Lehtinen et al. 2014, Bravo-Valencia and Delia 2016, Hughey et al. 2017). Possibly, the process of moving pairs into captivity during amplexus and oviposition disturbed the frogs such that the males did not fertilize all the eggs in the clutch. As an alternative, it is possible that this is a characteristic of this species, as reports of E. prosoblepon brooding behavior in the wild indicate that in more than half of the observed oviposition events, females only remained in partial contact with their clutches and do not exhibit the "egg rotation" movements observed in other species with parental care, a behavior that may aid in egg fertilization (Jacobson 1985). Further studies are needed to confirm or reject this observation. However, it is important to note that, the actual percentage of developmental abnormalities in the wild may be difficult to determine given that other sources of mortality (i.e., fungal infections, predation) take place before failure to develop is detected (BravoValencia and Delia 2016); therefore, natural observations may underestimate the ocurrence of this source of mortality in species with shortterm care such as E. prosoblepon.

Our results contribute information about the natural history of Espadarana prosoblepon in a population from southwestern Costa Rica, contributing to the existing literature about the reproductive biology of this species (Jacobson
1985, Basto-Riascos et al. 2017a). We provide information about specific sources of embryo mortality, types of predators, and differences in clutch size, contributing useful data for future comparative studies of the reproductive and behavioral ecology of this species. Establishing the primary differences in the causes of mortality among species with prolonged parental care, short-term parental care, and without parental care, will facilitate future comprehensive studies within Centrolenidae and may elucidate the ecological factors involved in the evolution of male and female parental care behavior in glass frogs.

\section{Acknowledgments}

Funding was provided by the National Science Foundation's Research Experience for Undergraduates and the Organization for Tropical Studies at the Las Cruces Biological Station. We thank Rebecca Vera for her support during fieldwork, Piotr Naskrecki for species identification of the arthropod predators, and Scott Walter, Darko Cotoras, and Rafe Brown for their helpful feedback on earlier versions of this manuscript. Jesse Delia and an anonymous reviewer provided comments that greatly improved the manuscript. We are indebted to the staff of Las Cruces for their logistical support, especially Rodo Quiros Flores and Mauricio Barquero. This research was conducted under the Ministerio del Ambiente y Energía de Costa Rica, y Sistema Nacional de Areas de Conservación Scientific Research Permit number R-SINAC-PNI-ACLAP-031-2018.

\section{References}

Angeli, N. F., G. V. DiRenzo, A. Cunha, and K. R. Lips. 2015. Effects of density on spatial aggregation and habitat associations of the glass frog Espadarana (Centrolene) prosoblepon. Journal of Herpetology 49: 388-394.

Basto-Riascos, M. C., J. López-Caro, and F. Vargas-Salinas. 2017a. Reproductive ecology of the glass frog Espadarana prosoblepon (Anura: Centrolenidae) in an 
urban forest of the Central Andes of Colombia. Journal of Natural History 51: 2535-2550.

Basto-Riascos, M. C., J. López-Caro, and C. A. LondoñoGuarnizo. 2017b. Espadarana prosoblepon (Boettger 1892). Catalogo de Anfibios y Reptiles de Colombia 3: 52-61.

Blaustein, A. R., S. C. Walls, B. A. Bancroft, J. J. Lawler, C. L. Searle, and S. S. Gervasi. 2010. Direct and indirect effects of climate change on amphibian populations. Diversity 2: 281-313.

Bravo-Valencia, L. and J. Delia. 2016. Maternal care in a glassfrog: care function and commitment to offspring in Ikakogi tayrona. Behavioral Ecology and Sociobiology 70: 41-48.

Cisneros-Heredia, D. F. and R. W. McDiarmid. 2007. Revision of the characters of Centrolenidae (Amphibia: Anura: Athesphatanura), with comments on its taxonomy and the description of nex taxa of glassfrogs. Zootaxa 1572: 1-82.

Delia, J., D. F. Cisneros-Heredia, J. Whitney, and R. Murrieta-Galindo. 2010. Observations on the reproductive behavior of a Neotropical Glassfrog, Hyalinobatrachiumfleischmanni (Anura: Centrolenidae). South American Journal of Herpetology 5: 1-12.

Delia, J. R. J., A. Ramirez-Bautista, and K. Summers. 2013. Parents adjust care in response to weather conditions and egg dehydration in a Neotropical glassfrog. Behavioral Ecology and Sociobiology 67: 557-569.

Delia, J., L. Bravo-Valencia, and K. M. Warkentin. 2017. Patterns of parental care in Neotropical glassfrogs: fieldwork alters hypotheses of sex-role evolution. Journal of Evolutionary Biology 30: 898-914.

Delia, J., J. M. Rivera-Ordonez, M. J. Salazar-Nicholls, and K. M. Warkentin. 2019. Hatching plasticity and the adaptive benefits of extended embryonic development in glassfrogs. Evolutionary Ecology 33: 37-53.

Duellman, W. E. and L. Trueb. 1986. Biology of Amphibians. New York. McGraw-Hill Book Company. 670 pp.

Frost, D. R. (ed). 2019. Amphibian Species of the World: an Online Reference. Version 6.0 (12 October 2019). Electronic Database accessible at http://research.amnh. org/herpetology/amphibia/index.html. American Museum of Natural History, New York, USA.

Gosner, K. L. 1960. A simplified table for staging anuran embryos and larvae with notes on identification. Herpetologica 16: 183-190.

Guayara-Barragán, M. G., M. Bernal, and E. E. HernándezCuadrado. 2010. Centrolene prosoblepon (glass frog). Fungal infection. Herpetological Review 41: 61-62.
Guayasamin, J. M., S. Castroviejo-Fisher, L. Trueb, J. Ayarzagüena, M. Rada, and C. Vilà. 2009. Phylogenetic systematics of Glassfrogs (Amphibia: Centrolenidae) and their sister taxon Allophryne ruthveni. Zootaxa 116: 263-270.

Hayes, M. P. 1983. A technique for partitioning hatching and morality estimates in leaf-breeding frogs. Herpetological Review 14: 115-116.

Hawley, T. J. 2006. Embryonic development and mortality in Hyalinobatrachium pulveratum (Anura: Centrolenidae) of South-Western Costa Rica. Journal of Tropical Ecology 22: 731-734.

Hedman, H. D. and M. C. Hughey. 2014. Body size, humeral spine size, and aggressive interactions in the Emerald Glass Frog, Espadarana prosoblepon (Anura: Centrolenidae) in Costa Rica. Mesoamerican Herpetology 1: 499-508.

Hughey, M. C., J. Delia, and L. K. Belden. 2017. Diversity and stability of egg-bacterial assemblages: the role of paternal care in the glassfrog Hyalinobatrachium colymbiphyllum. Biotropica 49: 792-802.

Jacobson, S. K. 1985. Reproductive behavior and male mating success in two species of glass frogs (Centrolenidae). Herpetologica 41: 396-404.

Krohn, A. R. and J. Voyles. 2014. A short note on the use of humeral spines in combat in Espadarana prosoblepon (Anura: Centrolenidae). Alytes 31: 83.

Lehtinen, R. M., S. E. Green, and J. L. Pringle. 2014. Impacts of paternal care and seasonal change on offspring survival: a multiseason experimental study of a caribbean frog. Ethology 120: 400-409.

Magnusson, W. E. and J.-M. Hero. 1991. Predation and the evolution of complex oviposition behaviour in Amazon rainforest frogs. Oecologia 86: 310-318.

McCaffery, R. and K. Lips. 2013. Survival and abundance in males of the glass frog Espadarana (Centrolene) prosoblepon in Central Panama. Journal of Herpetology 46: $213-220$.

McDiarmid, R.W. 1978. Evolution of parental care in frogs. Pp. 127-147 in G. M. Burghardt amd M. Bekoff (eds), The Development of Behavior: Comparative and Evolutionary Aspects. New York. Garland STPM Press.

Pounds, J. A., M. P. Fogden, and J. H. Campbell. 1999. Biological response to climate change on a tropical mountain. Nature 398: 611-615.

Salgado, A. L. and J. M. Guayasamin. 2018. Parental care and reproductive behavior of the Minute Dappled Glassfrog (Centrolenidae: Centrolene peristictum). South American Journal of Herpetology 13: 211-219. 
Savage, J. M. 2002. The Amphibians and Reptiles of Costa Rica: A Herpetofauna Between Two Continents, Between Two Seas. Chicago and London. University of Chicago Press. 934 pp.

Touchon, J. C. and K. M. Warkentin. 2009. Negative synergism of rainfall patterns and predators affects frog egg survival. Journal of Animal Ecology 78: 715-723.

Vockenhuber, E. A., W. Hodl, and A. Amézquita. 2009. Glassy fathers do matter: egg attendance enhances embryonic survivorship in the Glass Frog Hyalinobatrachium valerioi. Journal of Herpetology 43: 340 344.

Vonesh, J. R. 2000. Dipteran predation on the arboreal eggs of four Hyperolius frog species in Western Uganda. Copeia 2000: 560-566.
Warkentin, K. M. 2000. Wasp predation and wasp-induced hatching of red-eyed treefrog eggs. Animal Behaviour 60: $503-510$.

Warkentin, K. M., C. R. Currie, and S. A. Rehner. 2001. Egg-killing fungus induces early hatching of red-eyed treefrog eggs. Ecology 82: 2860-2869.

Warkentin, K. M. 2011. Environmentally cued hatching across taxa: embryos respond to risk and opportunity. Integrative and Comparative Biology 51: 1-12.

Wells, K. D. 2007. The Ecology and Behavior of Amphibians. Chicago. University of Chicago Press. 1148 pp.

Editor: Jaime Bertoluci 